\title{
The Eemian/Early Vistulian development of the Solniki paleolake (north-eastern Poland) as shown by subfossil Cladocera
}

\author{
Monika Magdalena Niska* \\ Institute of Geography and Regional Study, Pomeranian University in Słupsk, Partyzantów 27, 76-200 Słupsk, Poland \\ *Corresponding author: monikaniska@wp.pl
}

\begin{abstract}
This work presents results of a paleolimnological study focussed on subfossil Cladocera analysis and on different aspects of the evolution of the Solniki paleolake during the Eemian/Early Vistulian period. The study aimed at the reconstruction of the long-term dynamics of this paleoecosystem and at defining the conditions (e.g., water level, trophic status and water temperature) of the ancient lake. Paleolacustrine deposits of ca. $10 \mathrm{~m}$ thickness were discovered at Solniki during cartographic works for the Trześcianka sheet of the Detailed Geological Map of Poland. This archives recorded one full-interglacial sequence (Eemian Interglacial), one interstadial warming (Brørup) and two stadial coolings (Herning and Rederstall) stages, which were confirmed by palynological analyses. The subfossil Cladocera fauna from the Solniki paleolake consisted in 17 species belonging to the families Bosminidae, Chydoridae, Sididae and Daphniidae. Littoral species were dominant (52\%), the most frequent of which were Alona affinis and Camptocercus rectirostris. The most abundance pelagic species were Eubosmina coregoni and Bosmina longirostris. The sediment species composition was quite similar to that of contemporary Central European lakes. The early and the late stages of Eemian Interglacial were likely the most favourable periods for the Cladocera development in the paleolake, in relation to higher water level, moderate water temperature and the mesotrophic state of water. A further ecologically favourable period was the Brørup Interstadial. The highest species richness, abundance, and diversity during the whole paleolake existence were recorded during these three periods. Surprisingly, the middle of the Middle Eemian Interglacial climate optimum appeared as an unfavourable period for the Cladocera growth as it was associated with decreasing water level and pronounced climate fluctuations. This sequence was also recorded by other studies of Eemian lakes in Central Europe.
\end{abstract}

Key words: Cladocera analysis; Eemian/Early Vistulian; NE Poland.

Received: July 2016. Accepted: December 2016.

\section{INTRODUCTION}

The sediments that accumulate year by year in natural lakes are a key source of information on past environmental and climate changes and the most valuable sediment archive are those spanning over longer time periods (Cohen, 2003). Sediments from contemporary temperate lake allow to track environment changes that have taken place after the end of the last glaciation (Szeroczyńska and Zawisza 2007, Nevalainen, 2013). However, information on earlier interglacial stages is precluded. In addition, lake changes during the Holocene were the result of the combination between natural processes and increasing human activities (Cheddadi, 1998). The effects of natural and human driven processes is difficult to be discriminated.

The analyses of sediments from ancient paleolakes, which existed and disappeared from the landscape only under the influence of natural processes, provided opportunity to study a period spanning across glaciation, the Late Saalian (syn. Wartanian, 160-140 ka), a warming period, Eemian Interglacial, and another cool period, Early Vistulian Glaciation.
Numerous localities with lacustrine sediments from the Eemian Interglacial (MIS 5e) are present in Europe. Up to date, more than 300 sediment profiles from the Eemian Interglacial have been discovered in Poland and analysed for pollens (Granoszewski, 2003; Bruj and Krupiński, 2001; Mamakowa, 1989; Dobracka and Winter 2001; Kupryjanowicz, 2008, Kupryjanowicz et al. 2004). The analyses of other proxies (e.g., lithology, stable isotopes, geochemistry, animal and plant remains, pigments) are still less frequent in sediments of Eemian age (Robertsson, 2000; Mirosław-Grabowska, 2005; Gandouin, 2007; Nazarova, 2012), though each one is able to add precious information to complete the picture of the past ecosystem.

Over 80 Eemian Interglacial sites have been discovered in north-eastern Poland (Kupryjanowicz, 2008). Numerous Eemian paleolakes of the northern Podlasie indicate that during the Eemian Interglacial, a sort of lake district existed in this region (Kupryjanowicz, 2008). Nevertheless archives spanning the Eemian Interglacial and the Vistulian Glaciation are rare, especially in areas which have been influence by the Vistulian ice-sheet. 
Solniki is one of two northern Podlasie sites which play a key role in the reconstruction of vegetation succession and climate changes over the last interglacial-glacial cycle, from the final stage of the Wartanian Glaciation (Late Saalian) to the end of the Early Vistulian (Kupryjanowicz, 2007). A paleolake sediment of ca. $10 \mathrm{~m}$ thickness was discovered at Solniki during cartographic works for the Trześcianka sheet of the Detailed Geological Map of Poland. Prof. M. Kupryjanowicz. started the palynological study of the Solniki profile demonstrating the Eemian and Early Vistulian age of the discovered paleolake (Kupryjanowicz et al., 2005; Kupryjanowicz, 2008). Subfossil Cladocera analysis was performed for this profile in order to complement and expand environmental information provided by the palynological data.

Subfossil Cladocera are an useful tools in paleolimnology. They are a widespread and well studied component of the microfauna in lakes and ponds, and are commonly used as environmental indicator in aquatic ecosystem management (Jeppesen et al., 2011). In fact distribution and abundance of Cladocera is affected by habitat properties (Korhola, 1990), as well as by factors such as trophy (Szeroczyńska, 1998a, Nevalainen and Luoto, 2016), acidification (Krause-Dellin and Steinberg, 1986), water temperature (Poulsen, 1944; Hofmann, 2000, Nevalainen et al., 2013) and fish predation (Jeppesen et al., 2001; Korhola and Rautio, 2001).

Subfossil Cladocera analyses in Poland provided detailed results for the last 13,000 years (Gąsiorowski, 2002; Szeroczyńska, 2006; Szeroczyńska and Zawisza, 2007). The capability of subfossil Cladocera to support the environmental reconstruction for contemporary lakes, led to considerable interest in the applicability of the methods to sediments from the period preceding the last glaciation.

Literature on Cladocera succession during the Eemian Interglacial is scarce, as only a few locations in the world have been examined, often preliminarly, for cladoceran subfossils (Tsukada, 1972; Kadota, 1975; Hann and Karrow, 1984, 1993). The first comprehensive analysis of subfossil Cladocera from Eemian lake sediments in Europe was performed in Denmark (Frey, 1962). In Poland, the first analyses were conducted with material obtained in Konin (Szeroczyńska, 1991). So far, Cladocera analysis of sediment from profiles of the Eemian age was performed in Poland and in northern Germany (Börner et al., 2015) for ca. 16 sites (Niska, 2008; Niska, 2015; Mirosław-Grabowska et al, 2016, Pawłowski, 2011). However, only three out of these profiles represent Eemian Interglacial and Early Vistulian sequences: Solniki, Kubłowo (Mirosław-Grabowska et al. 2016) and Ustków (Kołaczek et. al. 2016).

Very general results of the Cladocera analysis from the Eemian part of the Solniki paleolake profile have been previously published (Kupryjanowicz et. al, 2005;
Miroslaw-Grabowska, 2015). This paper presents for the first time full results of subfossil Cladocera analysis for the entire profile (Eemian Interglacial and Early Vistulian part - 3.0-1.0 m depth) of the Solniki paleolake sediments. The aim of this study was to reconstruct the evolution of the Solniki paleolake during its long existence, and its water conditions (water level, trophic state and water temperature) based on Cladoceran investigations. These results were compared to the previously published pollen data, which define the vegetation history of the surrounding area. Special attention was paid to the Early Vistulian period, because of the scarcity of investigation of subfossil Cladocera for this period.

\section{METHODS}

\section{Study site and chronology of the profile}

The Solniki site $\left(53^{\circ} 30^{\prime} \mathrm{N}, 23^{\circ} 12^{\prime} \mathrm{E} ; 143 \mathrm{~m}\right.$ asl $)$ is located in the central part of the Białystok Upland (NE Poland, Fig. 1), approximately $18 \mathrm{~km}$ south of Białystok and $\sim 4 \mathrm{~km}$ south-west of Zabłudów (Kupryjanowicz, 2008). The region's relief was formed by the Wartanian Glaciation (Saalian, Riss Glaciation) (Musiał, 1992). The maximal range of the last glaciation (Vistulian, Weischelian) lies $\sim 50 \mathrm{~km}$ north of this site (Marks, 2002). The paleolake lies $\sim 100 \mathrm{~m}$ east of the Solniki to Koźliki road, on the left bank of the river Czarna. The studied sediments fill the subglacial basin, which was formed during the Wartanian Glaciation (Kurek and Preidl, 2001) and extends over an area of $\sim 700 \times 300 \mathrm{~m}$. The paleolake is surrounded by moraine and kame hills.

Coring was carried out in the 1990's using a geological corer during the preparation of the Trześcianka sheet of the 1:50,000 (Detailed Geological Map of Poland, in a scale of Kurek and Preidl, 2001). The entire cored sequence was $162.50 \mathrm{~m}$ long, while lake deposits, were present at depths of between 3.00-11.00 m (Kupryjanowicz, 2008). The paleolake sediments mainly consisted of organic silts, whereas a peat layer was detected at 11.00$10.60 \mathrm{~m}$ depth below the surface, and appeared covered by a $3 \mathrm{~m}$ thick deposit of sand. The description of the lacustrine-mire series is shown in Tab. 1. Sediments from the Solniki paleolake profile have been made available for Cladocera analysis by courtesy of Prof M. Kupryjanowicz. High resolution pollen analysis was performed for the sediment section between 3.00 and $11.06 \mathrm{~m}$ (Kupryjanowicz, 2008). The lower part of the Solniki pollen profile represents the interglacial vegetation succession and its characteristic features allow for its unquestionable correlation with the Eemian Interglacial (Kupryjanowicz, 2008). Stages of vegetation opening are present in the middle part of the Pinus zone (S-7 L PAZ), which ended the Eemian succession. Five local pollen zones (from S- 
8 to S-12 L PAZ) distinguished in the upper part of the studied profile represent the Early Vistulian (Weichselian) - Herning Stadial, Brørup Interstadial sensu lato (or Amersfoort/Brørup Interstadial sensu stricto with cold oscillation between them) and Redestall Stadial (Kupryjanowicz, 2008). All local pollen assemblage zones determined in the Solniki profile strongly correspon to the regional zones distinguished by Kupryjanowicz (2008) for the northern Podlasie and by Mamakowa (1989) for the territory of Poland (Tab. 2). The Solniki deposits have not been radiometrically dated because the entire Eemian Interglacial is outside the range of radiocarbon dating, and the carbonate lacustrine sediments are very problematic for other absolute chronometric dating methods (Mirosław-Grabowska and Niska, 2007b; Kołaczek et al., 2012). Therefore, only the palynological analysis document the Eemian and Early Vistulian age of the Solniki paleolake deposits.

The present work refers to the stratigraphic nomenclature of Poland, where the Vistulian, Eemian and Wartanian periods correspond to marine isotope stages (MIS) 2-5d, 5e and 6, respectively (Pisias et al., 1984). The Vistulian is subdivided into Early (MIS 5d-a), Plenivistulian (Lower MIS 4, Middle MIS 3 and Upper Plenivistulian lower part of MIS 2), and Late Vistulian (upper part of MIS 2 and lowermost part of MIS 2). We correlated Eemian Interglacial with Ipswichian, Mikulinian and Sangamonian - MIS-5e, the Vistulian with the Western Europe Weichselian glacial period (syn. Würmian, Valda- ian, Devensian, Wisconsin - MIS-5e-MIS-1), and the Wartanian with the Late Saalian glacial period (syn. Riss II, Warthe Glaciation, Wolstonian) (Gibbard and Kolfschoten, 2004; Pisias et al., 1984). The Eemian Interglacial is correlated with the Marine Isotope Stage - MIS 5e (Oxygen Isotope Stages - OIS 5e) and the Early Vistulian is correlated with MIS 5d-c (Mangerud, 1989; Shackleton et al., 2003).

\section{Cladocera analysis}

Cladocera analysis was performed for the sediment section 3.00-11.00 m depth, with a resolution of 5-10 cm (overall 99 samples). The samples for Cladocera analysis were taken from the same sections analysed for pollen, but the resolution was constrained by the scarcity of the material left by pollen analyses. The samples $(1 \mathrm{~g})$ were prepared according to standard procedures (Frey, 1986). After removing the carbonates using $10 \% \mathrm{HCl}$, the samples were heated at $60^{\circ} \mathrm{C}$ with $10 \% \mathrm{KOH}$ for $20 \mathrm{~min}$. The residue was washed with distilled water and sieved through a $40-\mu \mathrm{m}$-mesh sieve. The samples were coloured with Safranine and identified with a light microscope at $100 \times, 200 \times$ and $400 \times$ magnification. When possible, a minimum of 200 remains of Cladocera were analysed, using five to seven slides from each sample. All Cladocera remains were counted in each slide (head shield, shell, postabdomen, postabdominal claws, antennules and others), and the conversion of counted remains to the total
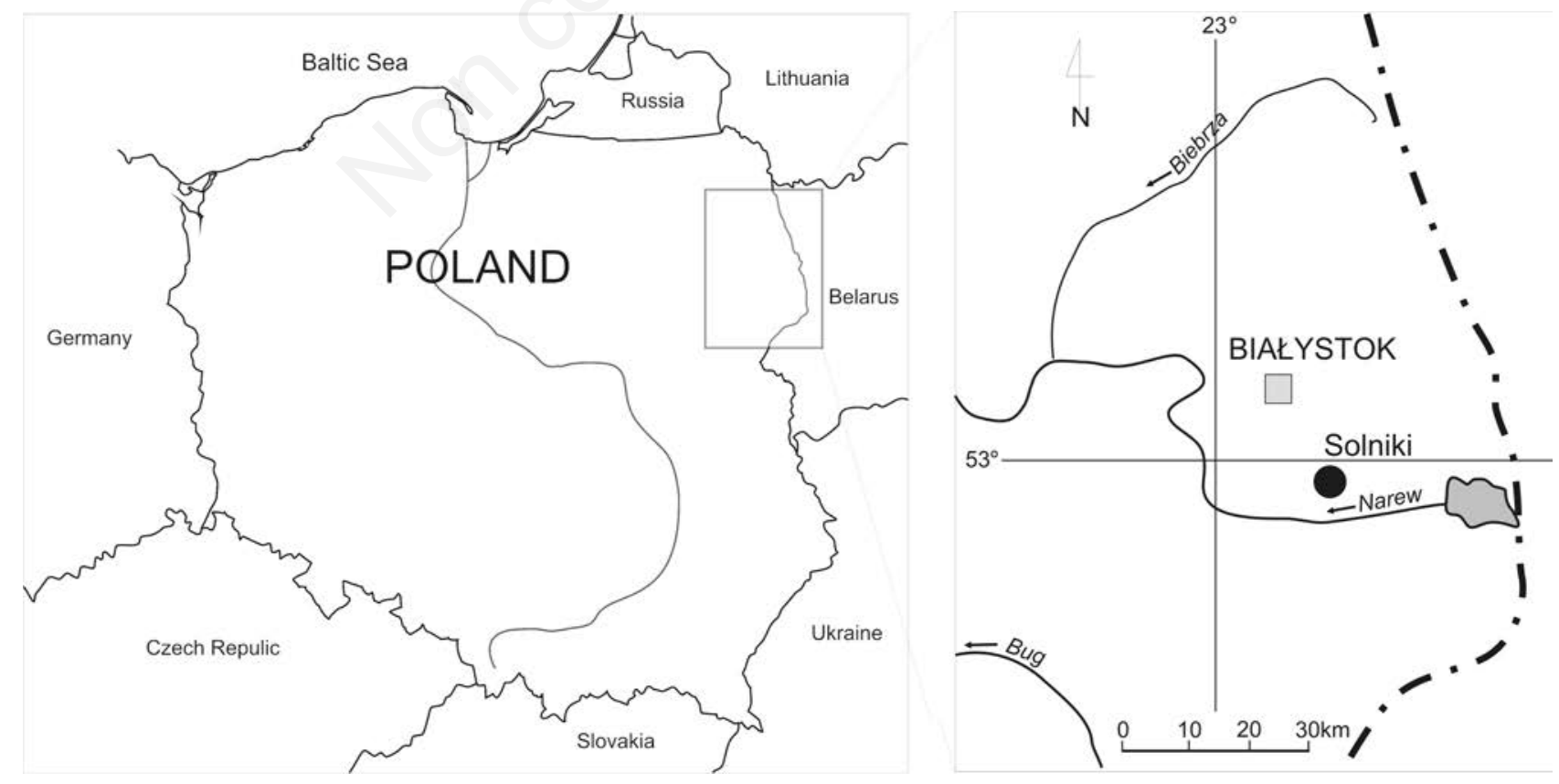

Fig. 1. Location of the Solniki paleolake. 
number of individuals was based on the most abundant type of remains for each taxon according to Frey (1986). The total number of Cladocera specimens in $1 \mathrm{~g}$ of sediment and the species diversity were assessed according to the Shannon-Wiener Diversity Index and plotted using the PolPal software (Nalepka and Walanus, 2003; Fig. 2). Identification of Cladocera remains and ecological interpretation were carried out according to Frey $(1958,1962)$, Goulden (1964), Szeroczyńska (1985, 1989), Hofmann (1986, 2000), Korhola (1990), Duigan (1992), Flössner (2000), Szeroczyńska and Sarmaja-Korjonen (2007), Rybak and Błędzki (2010), and Nevalainen et al. (2013), and Nevalainen and Luoto (2016).

All Cladocera species were classified into planktonic (pelagic) and littoral (meiobenthic) groups, with the latest group sub-categorised into three assemblages with different habitat preference, i.e. bottom-dwellers, species associated with vegetation and species restricted to vegetation (Flössner, 1964; Whiteside, 1970; Hofmann, 1987; Whiteside and Swindoll, 1988, Korhola, 1990). The species Chydorus sphaericus (O.F. Müller) and Bosmina longirostris (O.F. Müller) were assign to booth groups: lit- toral and open water zones because of their ability to migrate (Whiteside, 1970).

\section{RESULTS}

The results of qualitative and quantitative Cladocera analyses of the Solniki sediments are presented as absolute number of individuals in Fig. 3. The subfossil Cladoceran fauna of the Solniki paleolake are represented by 17 species belonging to the families Bosminidae, Chydoridae, Sididae and Daphniidae (Fig. 3). Fourteen of the identified species typically dwell within the littoral zone (Chydoridae). Three species occur mainly in the pelagic zone (Bosminidae, Daphniidae). Most of the remains belong to the families Bosminidae, with dominance of $E u$ bosmina coregoni (Baird), and Chydoridae, with a predominance of Alona affinis (Leydig) and Camptocercus rectirostris (Schoedler). These species prefer littoral zone in clear and calm waters in relation to the presence of aquatic plants (Flössner, 1972). Resting eggs of the $\mathrm{Ce}$ riodaphnia sp. have also been identified in the deposits.

Tab.1. Lithology of the Solniki profile (modified from Kupryjanowicz, 2008).

\begin{tabular}{ll} 
Depth $(\mathrm{m})$ & Sediment description \\
$3.00-3.90$ & Peaty silt with clay, dark grey; homogeneous, with plant detritus \\
$3.90-5.60$ & Organic silt with sand, slightly clayey, black \\
\hline $5.60-8.20$ & Organic clayey silt, brown-black \\
\hline $8.20-10.00$ & Organic clayey silt with small admixture of $\mathrm{CaCO}_{3}$ brown \\
\hline $10.00-10.60$ & Organic silt, black \\
$10.60-11.00$ & Peat, slightly clayey with traces of sand, black \\
\hline
\end{tabular}

Tab. 2. Correlation of local pollen assemblage zones (L PAZ) from the Solniki profile with regional pollen assemblage zones distinguished for Poland (R PAZ) and chronostratigraphical units and oxygen isotope stages (modified from Mirosław-Grabowska et al., 2015).

\begin{tabular}{|c|c|c|c|c|}
\hline $\begin{array}{l}\text { Local pollen assemblage } \\
\text { zones- L PAZ according } \\
\text { to Kupryjanowicz, } 2008\end{array}$ & $\begin{array}{l}\text { Regional pollen assemblage } \\
\text { zones- R PAZ according } \\
\text { to Mamakowa, } 1989\end{array}$ & Chronostratygraphy & & $\begin{array}{l}\text { Oxygen isotope } \\
\text { stages according } \\
\text { to Pisias et al., } \\
1984 \text { (OIS) }\end{array}$ \\
\hline S-12 Artemisia-Poaceae & $\begin{array}{l}\text { EV3 Graminae-Artemisia- } \\
\text { Betula nana }\end{array}$ & EV3 Rederstall Stadial & \multirow{3}{*}{ 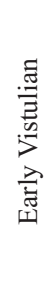 } & $5 b$ \\
\hline $\begin{array}{l}\text { S-11 Pinus-Betula } \\
\text { S-10 Artemisia-Betula } \\
\text { S-9 Betula }\end{array}$ & EV2 Betula-Pinus & $\begin{array}{ll}\text { Brørup s.s. } & \text { EV2 Brørup } \\
\text { Cool osc. } & \text { Interstadial } \\
\text { Amersfoort } & \text { Sensu lato }\end{array}$ & & $5 c$ \\
\hline $\begin{array}{l}\text { S-8 Artemisia-Cyperaceae- } \\
\text { Poaceae- Betula nana }\end{array}$ & $\begin{array}{l}\text { EV1 Graminae-Artemisia- } \\
\text { Betula nana }\end{array}$ & EV1 Herning Stadial & & $5 d$ \\
\hline $\begin{array}{l}\text { S-7 Pinus } \\
\text { S-6 Picea-Alnus-Carpinus-Pinus }\end{array}$ & $\begin{array}{l}\text { E-7 Pinus } \\
\text { E-6 Picea-Abies-Alnus }\end{array}$ & Late & \multirow{3}{*}{ 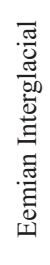 } & $5 e$ \\
\hline $\begin{array}{l}\text { S-5 Carpinus-Alnus } \\
\text { S-4 Corylus-Alnus-Tilia } \\
\text { S-3 Quercus-Ulmus-Fraxinus }\end{array}$ & $\begin{array}{l}\text { E-5 Carpinus-Corylus-Alnus } \\
\text { E-4 Corylus-Quercus-Tilia } \\
\text { E-3 Quercus-Fraxinus-Ulmus }\end{array}$ & Middle & & $5 e$ \\
\hline $\begin{array}{l}\text { S-2 Pinus-Salix-Quercus-Ulmus } \\
\text { S-1 Pinus-Betula-Picea }\end{array}$ & $\begin{array}{l}\text { E-2 Pinus-Betula-Ulmus } \\
\text { E-1 Pinus-Betula }\end{array}$ & Early & & $5 \mathrm{e}$ \\
\hline
\end{tabular}


Different frequency and concentration enables to distinguish six Cladocera assemblage zones (CAZ) in the Solniki profile (Figs. 2 and 3).

\section{Zone CAZ I (11.00-9.90 m)}

Up to 12 species per samples are present in this section, and total number of Cladocera individuals is around 950 ind $\mathrm{g}^{-1}$ The predominant species are Eubosmina coregoni (max. 76\% of total Cladocera abundance, Figs. 2 and 3), A. affinis (max. about 32\%), and Eurycercus lamellatus (O.F. Müller) (max. about 25\%). Ch. sphaericus and Sida crystallina (O.F. Müller) are also present. Pelagic species (E. coregoni and Ceriodaphnia sp. toward the end of this zone) and taxa related to aquatic vegetation are dominant. Finally, two species of the group connected with the bottom are present in this zone, i.e. Monospilus dispar (Sars) and Pleuroxus uncinatus (Baird) (vegetation/bottom species). The central part of this zone shows the highest diversity index (0.78; Fig. 2).

\section{Zone CAZ II (9.90-8.15 m)}

Due to differences in the frequency of species and specimens Zone II, is divided into two subzones.

\section{Subzone CAZ II A $(\mathbf{9 . 9 0 - 9 . 3 5 ~ m ) ~}$}

The number of individuals increases up to 2100 ind. $\mathrm{g}^{-}$

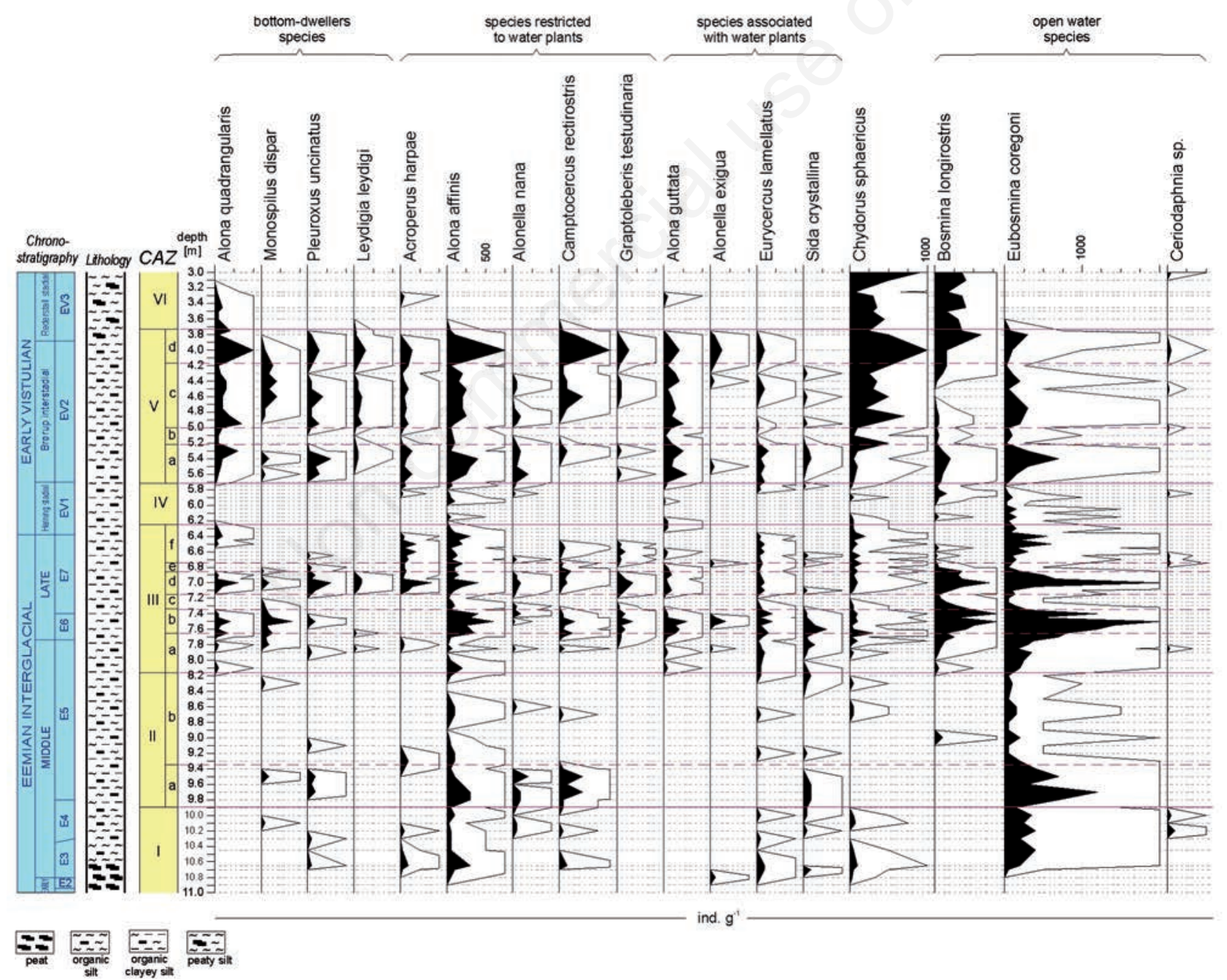

Fig. 2. Diagram of the total number of Cladocera specimens and species richness diversity and ratio of planktonic to littoral form - $\mathrm{P} / \mathrm{L}$ in the sediments of the of Solniki profile. L PAZ, local pollen assemblage zones (according to Kupryjanowicz, 2008); CAZ, Cladocera assemblage zones; exl., exclude; B. long, Bosmina longirostris; Ch. sph., Chydorus sphaericus; O, oligotrophy; M, mesotrophy; E, eutrophy; the arrows indicate increase and decrease in the lake water level. Explanations of lithology in Fig. 3. 
${ }^{1}$ of sediments (Fig. 2), while species richness decreases down to 8. As in the previous zone, three species are dominant: E. coregoni (max. about 57\%), A. affinis (27\%) and C. rectirostris (max 19\%, Fig. 3). An increase in the share of species from the group restricted to vegetation is recorded in this zone, while only E. coregoni represents the open water group. The diversity index is low (0.69-1.1).

\section{Subzone CAZ II B (9.35-8.15 m)}

The total number of individuals decrease down to 400 ind. $\mathrm{g}^{-1}$, while species richness increases up to 11 (Fig. 2). $A$. affinis and E. coregoni are the dominant species. Species of the group associated with water plants are the most abundant. The diversity index is the same as in the previous subzone 0.68 (max 1.1).

\section{Zone CAZ III (8.15-6.25 m)}

Zone III is distinguished due to the similarity of species composition in the samples and distinct separation from the rest of the zones. However, due to differences in the number of individuals of each species is divided into 6 subzone.

\section{Subzone CAZ III A (8.15-7.68 m)}

Species richness increases (up to 17), as well as the abundance of species of all groups (Fig. 3). The total number of individuals increases to a max. of about 1400 ind $\mathrm{g}^{-1}$ (Fig. 2). Bosminidae are dominant, with E. coregoni (max about $50 \%$ ), B. longirostris, and species associated with vegetation, such as $A$. affinis, E. lamellatus, small Alona and S. crystallina. Species connected with the sediment, such as Alona quadrangularis (O.F. Müller) and Leydigia leydigi (Schoedler) are found for the first time in the sediment record, as well as Graptoleberis testudinaria (Fischer), small Alona and Alonella exigua (Lilljeborg), which are related to connected high nutrient levels.

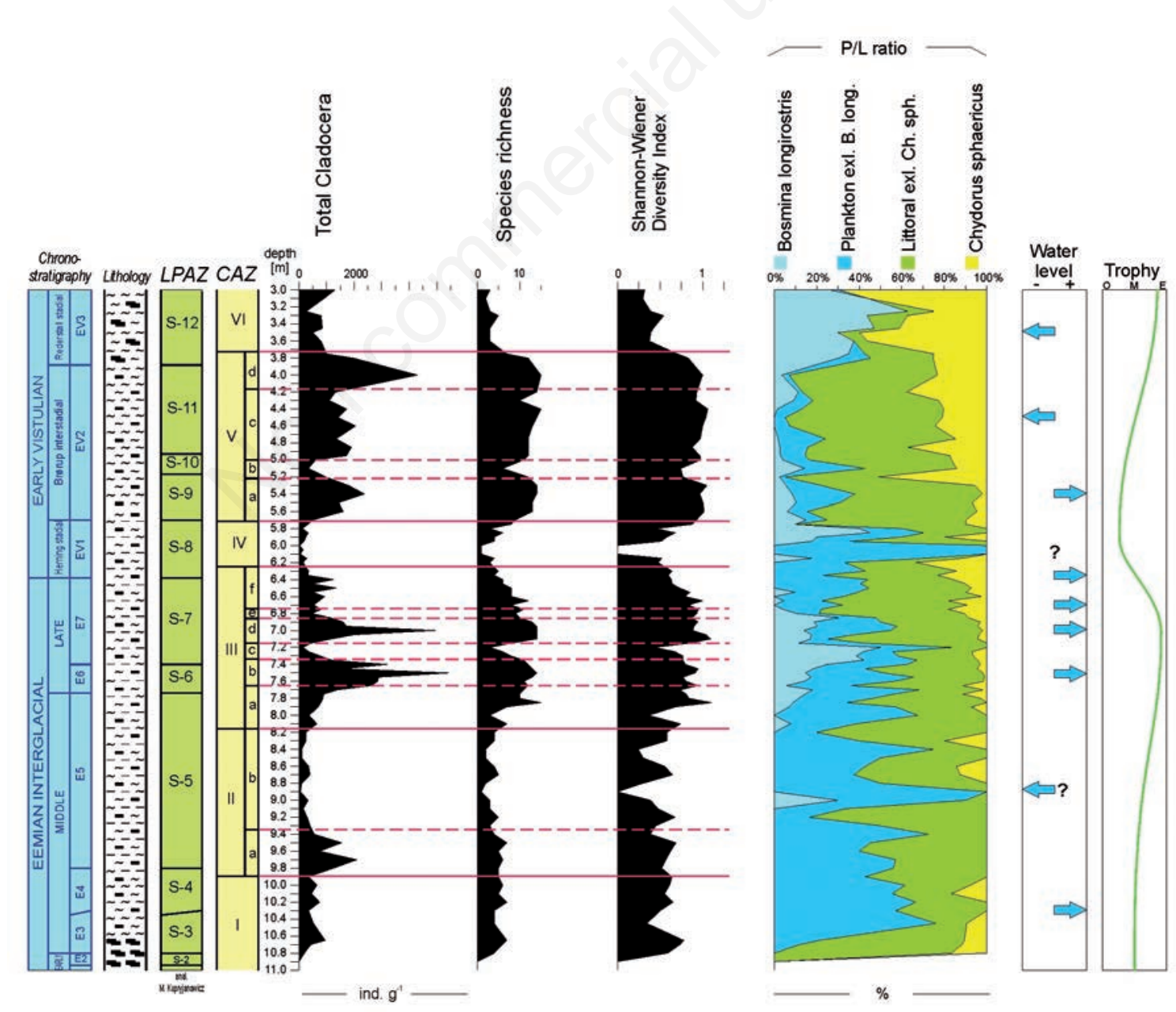

Fig. 3. Diagram of the absolute number of Cladocera specimens in the sediments of Solniki profile. CAZ, Cladocera assemblage zones. 
The diversity index increases up to 0.74 .

\section{Subzone CAZ III B (7.68-7.36 m)}

Total abundance of individuals father increases (up to 5400 ind. $\mathrm{g}^{-1}$ ), while the species richness slight decrease (15; Fig. 2). Bosminidae family predominates also in this zone with E. coregoni and B. longirostris (up to 2000 ind $\mathrm{g}^{-1}$ ). The abundance of littoral species $A$. affinis, $S$. crystallina, small Alona, E. lamellatus and Ch. sphaericus increases. The increase in species like $M$. dispar and $A$. exigua indicates mesotrophic water status, while $L$. leydigi and Acroperus harpae (Baird) disappear. The presence of both cold-tolerant (A. affinis, E. lamellatus, Ch. sphaericus) and warm requiring species (C. rectirostris, $P$. uncinatus) are present, and diversity index increases up to 0.95 .

\section{Subzone CAZ III C (7.36-7.14 m)}

Species richness decreases down to 11 in this zone, as also the total number of Cladocera (maximum $=1200$ ind $\mathrm{g}^{-1}$ ). B. longirostris (about 50\%, Fig. 3), E. coregoni and A. affinis predominate, while some species tolerating cold water are also present. The diversity index decreases again down to 0.84 .

\section{Subzone CAZ III D (7.14-6.88 m)}

The conditions for zooplankton development improve as indicated by the increase in the abundance of both littoral and planktonic species (similarly as in the CAZ II B subzone). Values of diversity index are above 1.1, and both species richness (up to 15) and total Claodcera abundance (up to 4950 ind $\mathrm{g}^{-1}$ ) increase. Dominant species are E. coregoni (max. 2000 ind $\mathrm{g}^{-1}$ ), B. longirostris and $A$. affinis. Species preferring high water nutrient (P. uncinatus, L. leydigi, G. testudinaria) and warmer water (C. rectirostris and $P$. uncinatus) reach higher frequencies. Nevertheless both cold-tolerant and warm water-requiring species are present.

\section{Subzone CAZ III E (6.88-6.72 m)}

This subzone is characterized by a decreasing abundance of specimens (to 1150 ind $\mathrm{g}^{-1}$; Fig. 2) and species richness (12). Species associated with water plants $(A$. affinis, A. harpae, E. lamellatus and Ch. sphaericus) are dominant, and B. longirostris and E. coregoni are also numerous. The diversity index decreases down to 0.94 .

\section{Subzone CAZ III F (6.72-6.25 m)}

Both species richness and total Cladocera abundance decrease (down to 13 and 1350 ind $\mathrm{g}^{-1}$, respectively; Fig. 2). Littoral species such as A. affinis, A. harpae, A. quadrangularis, and $C h$. sphaericus dominate in this zone. $E$. coregoni is the dominant pelagic species (Fig. 3). Except for A. quadrangularis, there are no species associated with the bottom. Taxa preferring a high temperature of water (C. rectirostris, P. uncinatus, G. testudinaria) are identify in the second part of this subzone.

\section{Zone CAZ IV (6.25-5.71 m)}

Species richness and total abundance of individuals further decrease down to 9 and 330 ind g $^{-1}$ (Fig. 2). Only cold-tolerant species (i.e., A. affinis, Ch. sphaericus, E. coregoni and $B$. longirostris) remain in the lake. The disappearance of species preferring warm waters (Pleuroxus sp., C. rectirostris) disappear and the diversity index varies from 0.00 to 0.88 .

\section{Zone CAZ V (5.71-3.72 m)}

This zone is distinguished due to the similarity of species composition in the samples and distinct separation from the rest of the zones. However, due to differences in the number of individuals of each species is divided into four subzone. Almost all species identified in the previous zones are present again in this zone.

\section{Subzone CAZ V A (5.71-5.21 m)}

This zone is characterized by the increase in frequency of both littoral and planktonic species. Species richness increases up to 16 (Fig. 2) and the total number of indi-

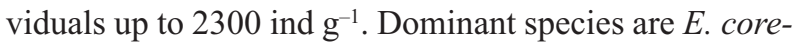
goni and B. longirostris, A. affinis, small Alona, and $A$. quadrangularis. Both thermophilic (e.g., P. uncinatus, and C. rectirostris) and cold water-tolerant species (e.g., A. harpae, E. lamellatus), as well as species requiring more fertile water (e.g., L. leydigi, B. longirostris) are present. Diversity index increases up to 1.05 .

\section{Subzone CAZ V B (5.21-5.02 m)}

Total Cladocera abundance drops again down to 970 ind $\mathrm{g}^{-1}$. Species richness decreases down to 13. Cold-tolerant species (Ch. sphaericus, A. affinis, small Alona) are dominant (Fig. 3), and diversity index is low (max. 0.77).

\section{Subzone CAZ V C (5.02-4.18 m)}

Both species richness and total number of individuals increased (up to 17 species and $2050 \mathrm{ind} \mathrm{g}^{-1}$; Fig. 2). The most abundant species are Ch. sphaericus, E. coregoni, $C$. rectirostris and A. affinis. The diversity index rises up to 1.0.

\section{Subzone CAZ V D (4.18-3.72 m)}

The abundance of all species significantly increases and the total number of Cladocera reaches 4300 ind $\mathrm{g}^{-1}$. On the contrary, species richness decreases down to 15 . Species associated with water plants (A. affinis, C. rectirostris) and with the bottom (A. quadrangularis and $C h$. 
sphaericus) are dominant, but also species requiring either warm waters (C. rectirostris, G. testudinaria and P. uncinatus) or high nutrient level (B. longirostris, A. quadrangularis, L. leydigi and Ch. sphaericus) are present. $S$. crystallina and Alonella nana (Baird) disappear in this zone. The diversity index remains around 1.0.

\section{Zone CAZ VI (3.72-3.00 m)}

The abundance of all species decreases, except for $C h$. sphaericus and B. longirostris, which are predominant. Total individual number drop down to 1300 ind $\mathrm{g}^{-1}$, and species richness decreas down to 6 . The presence of coldwater tolerant species, such as $A$. harpae, Ch. sphaericus, small Alona and B. longirostris, are present, and the diversity index drops down to 0.54 .

\section{DISCUSSION}

The subfossil Cladocera analysis conduct on the Solniki profile provide information on the paleolake evolution during the Eemian Interglacial and the early Vistulian Glaciation (EV1-EV3). The remains are well preserve and abundant considering the old age of the sediments, and the Cladocera species composition is comparable to what found in different Central European lakes (Szeroczyńska and Zawisza, 2007) and Eemian paleolakes, such as Kaliska, Studzieniec, Ruszkówek, Kuców IIc (Niska, 2012), Sławoszewek (Pawłowski, 2011), Imbramowice (Mirosław-Grabowska and Gąsiorowski, 2010), and in Herning paleolake (Frey, 1962).

\section{Lake evolution of the Solniki paleolake during the Eemian-Vistulian}

Solniki Paleolake develop in a melt depression at the end of Late Saalian Glaciation, while the lake sedimentation starts at the onset of the Early Eemian (Kupryjanowicz, 2008), when the improvement of climatic conditions and the weakening of periglacial processes chang the vegetation surrounding the lake and allow the development of the biological community within the new lake.

\section{Early Eemian}

Local Pollen Assemblage zone (L PAZ) S-1 (PinusBetula-Picea), Regional Pollen Assemblages Zone (R PAZ) E1, L PAZ S-2 (Pinus-Salix-Quercus-Ulmus), R PAZ E2, begging of CAZ I. During the early Eemian, the area surrounding the lake initially develop boreal pine forests with quite a large share of spruce (L PAZ S-1). This may indicate a cool, relatively humid climate. In the period corresponding with zone L PAZ S-2, in the place of spruce enter more demanding trees in terms of temperature, such as oak and elm. The willow, inhabiting moist land (Kupryjanowicz et al., 2004, Kupryjanowicz, 2008) also reach its maximum growth.

No Cladocera remains are find in the studied sediment profile at the very beginning of the early Eemian, due to the peaty condition of the early stage of the new lake, while the following samples are characterize by the presence of Ch. sphaericus and A. affinis (CAZ I), which are consider as pioneer species due to their tolerance to low water temperature and wide tolerance to environmental conditions (Whiteside, 1970; Hofmann, 2000).

Similar species composition at the beginning of the early Eemian is observed also in other polish lakes, such as Starowlany paleolake and Kubłowo paleolake (Niska and Roman, 2014; Niska and Kołodziej, 2015), as well as in central and northern european lakes (Szeroczyńska, 1985; Sarmaja-Korjonen and Alhonen, 1999; Gąsiorowski and Szeroczyńska, 2004).

\section{Middle Eemian}

L PAZ S-3 (Quercus-Ulmus-Fraxinus) - R PAZ E3, L PAZ S-4 (Corylus-Alnus-Tilia) - R PAZ E4, L PAZ S-5 (Carpinus-Alnus) - R PAZ E5, CAZ I, CAZ II, CAZ IIIA.

The interglacial climatic optimum starts with oak-elm forests with a fairly large share of ash (Fraxinus) (L PAZ $\mathrm{S}-3, \mathrm{E} 3)$. They are most likely riparian forests, where the role of the pine is significantly lower and hazel (Corylus) gradually spread in the undergrowth. Multispecies of thermophilic deciduous forests successively develop (L PAZ S-4, E4), with hazel (Corylus) and lime tree (Tilia) reaching their optimum growth, and elm (Ulmus), oak (Quercus) and hornbeam (Carpinus), and rarely (Fraxinus) as accompanying species. Alder forests are growing on the wetlands areas. All types of forests show low share of Non-Arboreal Pollen grains (NAP), which did not exceed $2 \%$.

During the Middle Eemian the peat depositions are replace by silt. Moreover the Cladocera composition show a change in specie assemblages. In fact, despite the constant dominance of the pioneer specie $A$. affinis at the beginning of the zone (CAZ IIA), several Cladocera species are also identify in this part of the profile. A. nana and $E$. coregoni appear for the first time suggesting oligo/mesotrophic conditions. The presence of the planktonic $E$. coregoni indicates an increase in water depth (Hofmann, 1993). Moreover, the identification of P. uncinatus, $C$. rectirostris and $M$. dispar reveal a progressive increase in water temperatures (Poulsen, 1944; Frey, 1958), while the presence of species associated to water plants (i.e., A. harpae, A. affinis, A. nana, E. lamellatus) suggest a development of the macrophyte zone.

In the next period (L PAZ S-5 - R PAZ E5), forests dominated by hornbeam absolutely prevail in the majority of habitats These hornbeam forest has also initially a relatively high share of hazel, lime tree and elm. Spruce (Picea) appears and gradually spread, the role of pine and birch also 
increas The humid places are dominated by alder forests. The recorded pollen trees suggest hotter and longer summers than in the zone L PAZ S-4, and still mild winter (Kupryjanowicz, 2008; Niska, 2008). Mainly cold water tolerant species, i.e. A. harpae, E. lamellatus and Ch. sphaericus are identify in this sediment section. However, the increase in C. rectirostris, P. uncinatus and $M$. dispar suggests an improvement in climatic conditions The sedimentation of silt is replace by gyttja, which may indicate a deepening of the reservoir, in agreement with the increase in abundance of pelagic species, such as E. coregoni.

The next stage (CAZ II B) bring a deterioration of habitat conditions in the reservoir. Initially only the summer temperature decreased (Kupryjanowicz, 2008), but the palynological analysis indicates a later winter tightening and a climate drying (Kupryjanowicz et al., 2004). At that time, a significant reduction in the abundance of Cladocera is observed in the other Eemian sites in Poland, e.g., Kaliska, Ruszkówek and Kubłowo (Mirosław-Grabowska and Niska, 2007a; MirosławGrabowska et al., 2009; Niska and Roman, 2014). In paleolake Herning, a drop in the abundance of Cladocera is noted at the end of R PAZ E4 and the beginning of R PAZ E5 (Frey, 1962).

The observed decrease in total Cladocera abundance in this sediment section, together with the dominance of A. affinis and E. coregoni, confirm the decrease in water temperature, and suggest a correspondent decrease in water level and in the lake trophic status. The degradation of the living conditions in the lake could be associate not only to the low water temperatures but also to the reduction in the water level. In fact Kupryjanowicz (2007) show that most of the Eemian paleolakes from the northern Podlasie region dried at that time, producing a terrestrialization of several shallow lakes and bogs. At that time, a significant reduction in the Cladocera abundance is observed in the other Eemian sites in Poland, e.g. Kaliska, Ruszkówek and Kubłowo (Mirosław-Grabowska and Niska, 2007a; Mirosław-Grabowska et al., 2009; Niska and Roman, 2014).

At the end of this period, a further cooling occurs with a simultaneous increase in climate humidity (Kupryjanowicz et al., 2004).

The slight increase in Cladocera remains (CAZ IIIA) and in particular in E. coregoni suggested a new stage of high water depth, while the presence of species associated with water plants, such as $A$. affinis, E. lamellatus, and $S$. crystallina, indicat an expansion and a development of the macrophytes zone. Moreover, the identification of $M$. dispar and A. exigua in this zone suggest mesotrophic conditions (Adamska and Mikulski, 1968).

\section{Late Eemian}

L PAZ S-6 (Picea Alnus-Fraxinus-Pinus) - R PAZ E6, L PAZ S-7 (Pinus) - R PAZ E 7, CAZ III B-F.
The Late Eemian Interglacial period is characterized by the maximum development of spruce. Pine, fir (Abies) and larch (Larix) are dominant, along with some deciduous trees such as birch (Betula) and hornbeam (Carpinus). These trees can form different types of coniferous and mixed forests. Also, alder (Alnus) is present in pretty large quantities (Kupryjanowicz et al., 2004; Kupryjanowicz, 2008; Niska 2008).

The total Cladocera abundance and species diversity indicates that it was one of the most favourable periods for the development of zooplankton in the lake.

During the late Eemian the Cladocera community register rapid increases (CAZ III B-D-F) alternate to drastic decreases in species diversity and abundance (CAZ III C-E), suggesting a continuous change from favourable to unfavourable lake conditions for the zooplankton development. In particular, in CAZ III B-D-F, the simultaneous presence of the planktonic species E. coregoni and B. longirostris indicate an increase in the trophic level (Boucherle and Zullig, 1983; Szeroczyńska, 1985, 1991; Frey, 1986; Nauwerck, 1991; Dimante-Deimantovica et al., 2012), which is also confirmed by the presence of $M$. dispar and A. exigua. Moreover the identification of $C$. rectirostris, P. uncinatus and $G$. testudinaria reveals an increase in water temperatures (Szeroczyńska, 1985; Hofmann, 2000), while remains of $A$. harpae, A. quadrangularis and L. leydigi suggest a continuous development of the macrophyte zone. The CAZ III C-E periods are characterized by low Cladocera abundances and by the presence of the cold water tolerant species $A$. affinis, E. lamellatus and A. nana, suggesting deteriorated ecological conditions due to the low water temperatures.

Similar Cladocera trends during the Late Eemian is documented in the other paleolakes, e.g., Kuców IIc (Niska, 2008), Kaliska and Kubłowo from central Poland (Mirosław-Grabowska and Niska, 2007a; Niska and Roman, 2014), indicating a comparable regional influence on the Cladocera community by regional climate development. On the other hand, although the Cladocera species diversity and abundance increase in the Herning paleolake as in the other paleolakes, changes in species frequency are not so significant due to the smaller differences in the climate condition and more moist (oceanic) climate (Mirosław-Grabowska et al., 2016). The pollen assemblages in Solniki paleolake confirm that the late Eemian is a period characterized by short-term colder and warmer events (Kupryjanowicz, 2008).

\section{Early Vistulian, Herning stadial}

L PAZ S - 8 (Artemisia-Cyperaceae-Poaceae- Betula nana) - R PAZ EV1, CAZ IV

The Herning stadial was the first post-eemian cold period in northern Podlasie. The Solniki core are characterize by a high content of clay and sand, which indicate a diluvial and/or eolic genesis of these deposits in relation 
to a stage of climate cooling and increasing humidity. At that time, vegetation of the studied region is predominantly represented by tundra, composed by willow clusters, possibly enriched with shrub birches. Trees were likely present only in form of small patches of pine and birch(Kupryjanowicz, 2008).

In this zone, a pronounced decrease of the subfossil cladoceran fauna are observed. As registered also in other polish lakes between the end of the Eemian Interglacial and the beginning of the Vistulian (i.e., Kubłowo, Ustków, Rzecino; Niska, 2015). Cladocera assemblages is composed by the sole species tolerating low water temperatures, such as A. affinis, Ch. sphaericus, B. longirostris and $E$. coregoni, suggesting a significant reduction of the water temperatures.

\section{Early Vistulian, Brorup}

L PAZ S-9 (Betula), Amersfoort, S-10 (Artemisia-Betula) (cool oscillation), S-11 (Pinus-Betula), Brørop sensu stricto, R PAZ EV2, CAZ V A-D

In the older part of the Brørup sensu lato Interstadial (S-9 Betula L PAZ), which may be correlated to the Amersfoort Interstadial distinguished in Western Europe, signs of a climate improvement are observed (Kupryjanowicz, 2008). Birch forests spread at the cost of areas occupied by herbaceous plant communities. Dry habitats remain covered by steppe communities, whereas wet habitats are still occupied by grass communities similar to contemporary damp meadows. Pine trees (Pinus sylvestris type (Linneaus) become an essential component of birch forests or even formed separate assemblages.

At the beginning of the Brørup (Early Vistulian, CAZ V A) Cladocera abundances and diversity increase. The presence of thermophilous species such as $P$. uncinatus and $C$. rectirostris indicates higher water temperatures, although species tolerating cool water (e.g., A. harpae and E. lamellatus) are still present. The increase in L. leydigi and $B$. longirostris suggest an increase in the lake nutrient levels (Alhonen, 1970; Szeroczyńska, 2002). The high abundance of the family Chydoridae associated to aquatic vegetation may indicate a new stage of macrophyte development. Finally, the increase in E. coregoni may reveal another rise in water level. As outlined by the pollen analysis, the climate in this period is more humid and characterize by higher rainfall events (Kupryjanowicz, 2008), which may confirm the hypothesis of a higher lake water depth. The period of favourable conditions for the Cladocera development is interrupted by a rapid cooling stage (L PAZ S-10, CAZ V B), which, in the northern Podlasie, is reflected by a spread of the area covered with cold steppe communities lush with Artemisia, Chenopodiaceae, Anthemis type, Caryophyllaceae undiff., and some grasses (Kupryjanowicz, 2008).

The subfossil cladoceran community are represent in this stage only by species tolerant of cold water, such as A. quadrangularis, A. affinis, Ch. sphaericus, B. longirostris and E. coregoni. Despite a short period of cold water temperatures characterized by a decrease in Cladocerea abundances (CAZ V B), the favourable conditions for the Cladocera growth continue throughout the entire Brørup Interstadial (CAZ V C-D). This period are characterize by species preferring warm water temperatures and the replacement of $E$. coregoni by $B$. longirostris suggest a reduction in the lake water level and an increase in the lake trophy (Hofman 1987; Szeroczyńska, 1998b; Nevalainen et al., 2013). The high Cadocera abundance and diversity in this period reveal an improvement of the water living conditions, which is also observed in Kubłowo lake (Niska and Roman, 2014). The pollen analysis by Kupryjanowicz (2008) highlight a boreal forest spread, which confirmed the improving of the climate conditions.

\section{Early Vistulian, Rederstall Stadial}

L PAZ S-12 (Artemisia-Poaceae) - R PAZ EV3, CAZ VI

The cold continental climate of the Rederstall stadial led to the spreading of cold steppe communities. Betula nana type (Linneaus) and shrub Salix form a dwarf shrub tundra, while forest communities declined. In the Rederstall Stadial (Early Vistulian) the Cladocera abundance and diversity decrease (CAZ VI). Cold water tolerant species are present, e.g., A. harpae, and Ch. sphaericus, as well as species indicating high concentration of organic matter in the water column, e.g., B. longirostris, small Alona, A. quadrangularis, and Ch. sphaericus (Duigan, 1992). The dominance of Ch. sphaericus and B. longirostris suggests eutrophic lake conditions and general deterioration of the ecological quality (Szeroczyńska 1991). In fact, both taxa are widely tolerant to environmental stress, and they are often the last cladoceran inhabitants of shallowing water bodies in palaeorecords (Nováková, 2005). Cladocera record for the Rederstal stadial period are available in Poland only for other two lakes: Kubłowo (Miroslaw-Grabowska at al., 2016) and Ustków (Kołaczek et al., 2016). In the Kubłowo profile wide tolerant species $C h$. sphaericus, A. quadrangularis and $A$. nana are dominant, as similarly recorded also in Solniki paleolake. On the other side, Cladocera community in Ustków profile appears to be dominated by B. longirostris, Ch. sphaericus and small Alona, which are species tolerating high environmental stress (Duigan, 1992). The Cladocerea assemblages of this two paleolake include also species preferring high water temperature (i.e., Pleuroxus sp., M. dispar, $C$. rectirostris), while the lack of thermophilic species in the Solniki paleolake could be the result of a more severe continental climate occurring in this area. 


\section{Water level changes}

The planktonic:littoral (P:L) ratio of Cladocera was used for the first time by Alhonen (1970) to investigate lake level changes during the Holocene. However, the interpretation of $\mathrm{P} / \mathrm{L}$ ratios should take into account that many other environmental variables, in addition to lake depth, can affect the share of pelagic and littoral of subfossil cladoceran assemblages (Gąsiorowski and Hercman, 2005; Nevalainen et al., 2008).

The large average share of deep-water species (48\%) in the Solniki profile suggests a persistent presence of a well-developed pelagic zone in the paleolake. Nevertheless, the depth profile of the P:L ratio shows a general predominance of shallow-water groups, such as Chydoridae and Sididea, which suggests the constant presence of a shallow littoral zone. During the Middle and Late Eemian Interglacal period the $\mathrm{P}: \mathrm{L}$ ratio reveals a rise in planktonic species, such as E. coregoni, B. lonigrostris and Ceriodaphnia spp, suggesting an increase in lake depth. The drastic decrease in littoral species and the presence of the sole planktonic taxa E. coregoni during the Herning stadial suggest that Solniki lake is still a deep lake during this stage. However, this result has to be considered as a fake since the L:P ratio did not take into account the general decrease in total Cladcocera abundance and species richness. This provides a confirmation of the necessity for a carefully interpretation of the P:L Cladocera ratio for paleoecological reconstructions. On the other hand, the Early Vistulian period shows a prevalence of littoral species, which can be read as a gradual lowering of the water level in the paleolake, which may have contributed to enlarge the shallow littoral zone.

\section{Lake trophic evolution}

Cladocera assemblages indicate that Solniki paleolake was nutrient poor for most of its existence. In fact, during the Middle Eemian the paleolake is dominated by species preferring oligotrophic conditions. An increase in the lake trophic condition, likely up to a mesoc-eutrophic level, occur during the Late Eemian, as indicated by the presence of M. dispar, A. exigua and B. longirostris (Adamska and Mikulski, 1968). The decrease in Cladocera abundances during the end of the late Eemian Interglacial and the Herning stadial suggests a new long stage of low nutrient concentrations. On the other hand, the presence of Ch. sphaericus and of B. longirostris in the final stage of the lake existence, reveal a second increase in nutrient concentrations till eutrophic conditions during the Brørup

CONCLUSIONS
CONtriat and the Rederstall Statial.

The unique character of the paleolake at Solniki consists in its very long, uninterrupted sedimentation that occurred during the entire Eemian Interglacial and Early
Vistulian. The detail Cladocera analysis showed that:

- The Cladocera remains preserve in sediments of the Solniki paleolake, despite their age, are well preserve. Their species composition are not substantially differ from those found in of other Eemian paleolakes and in contemporary Central European lakes. The species richness is slightly lower than in contemporary lakes but very similar to that of Eemian paleolake Starowlany (NE Poland).

- The most favourable periods for Cladocera development are identify at the beginning of the Eemian Interglacial during some stages of the Late Eemian and during the Brørup Interstadial, probably in relation to higher water level, warmer temperatures and moderate nutrient levels. Such favourable stages were also recorded in the other studied Eemian lakes from Central Europe.

- Unfavourable conditions for Cladocera community occur during the beginning of the Eemian Interglacial, the Middle Eemian (CAZ II B) and the Herning Stadial (CAZ IV), probably due to low lake water temperatures and nutrient level.

- Several major fluctuations in the lake water level are observe during the entire studied period, in relation to the alternation of warm and wet and dry and cold climate conditions.

- Cladocera assemblages suggest oligotrophic to oligomesotrophic conditions at the beginning of the lake existence, which are follow by a steady increase in nutrient concentrations till the final lake stage.

- Major changes in subfossil Cladocera frequency track the alternation of warmer and cooler temperatures throughout the entire studied period. Warmer water temperatures are recorded during the Early Eemian, the beginning of the Middle Eemian and the Brørup Interstadial, while colder temperatures are identified in the late Eemian, in Herning Stadial and again in the Rederstal Stadial.

\section{ACKNOWLEDGMENTS}

I would like to express my thanks to Prof. Mirosława Kupryjanowicz for the very interesting discussions. The Cladocera analysis was supported by the Foundation for Polish Science, Bridge Program 2012 - project: "Reconstruction of the development of lake environmental in the Eemian Interglacial based on subfossil Cladocera (Crustacea) analysis". Fieldworks, pollen and part of the Cladocera analysis were supported by the Ministry of Science and Higher Education, project 2PO4E 02329.

\section{REFERENCES}


Adamska A, Mikulski JS, 1969. Cladocera remains in the superficial sediments of lakes as a typologic indicator. Z. Naukowe UMK 25, Prace Stacji Limnolog w Iławie 5:41-48.

Alhonen P, 1970. On the significance of the planctonic/litoral ratio in the cladoceran stratigraphy of lake sediments. Comentat. Biol. 57:3-34.

Börner A, Hrynowiecka A, Kuznetsov V, Stachowicz-Rybka R, Maksimov F, Grigoriev V, Niska M, Moskal-del Hoyo M, 2015. Palaeoecological investigations and $230 \mathrm{Th} / \mathrm{U}$ dating of Eemian interglacial peat sequence of Banzin (Mecklenburg-Western Pomerania, NE-Germany). Quatern. Int. 386:122-136.

Boucherle MM, Züllig H, 1983. Cladoceran remains as evidence of change in trophic state in three Swiss lakes. Hydrobiologia 103:141-46.

Brodersen KP, Whiteside MC, Lindegaard C, 1998. Reconstruction of trophic state in Danish lakes using subfossil chydorid (Cladocera) assemblages. Can. J. Fish. Aquat. Sci. 55:1093-1103.

Bruj M, Krupiński KM, 2001. [Biogeniczne osady jeziorne interglacjału eemskiego w Żeliszczewie na Wysoczyźnie Siedleckiej].[Article in Polish]. Przegląd Geologiczny 49:583-543.

Cheddadi R, Mamakowa K, Guiot J, de Beaulieu JL, Reille M, Andrieu V, Granoszewski W, Peyron O, 1998. Was the climate of the Eemian stable? A quantitative climate reconstruction from seven European pollen records. Palaeogeogr. Palaeoclim. Palaeoecol. 143:73-85.

Cohen AS, 2003. Paleolimnology: the history and evolution of lake systems. Oxford University Press, New York.

Dimante-Deimantovica I, Skute A, Skute R, 2012. Vertical variability of pelagic zooplankton fauna in deep Latvian lakes, with some notes on changes in ecological conditions. Eston. J. Ecol. 61:247- 264.

Dickinson KA, 1959. The Ostracoda and Cladocera of the Humboldt Formation in northeastern Nevada. MS Thesis (unpublished), University of Minnesota.

Dobracka E, Winter H, 2001. [Stanowisko osadów Interglacjału eemskiego w profilu otworu Rzycino (Wysoczyzna Łobezka)].[Article in Polish]. Proceedings 8th Conf. "Stratygrafia Plejstocenu Polski" Jarnołtówek.

Duigan CA, 1992. The ecology and distribution of the littoral freshwater Chydoridae (Branchiopoda, Anomopoda) of Ireland with taxonomic comments on some species. Hydrobiologia 241:1-70.

Duigan CA, Birks HH, 2000. The late-glacial and early-Holocene palaeoecology of cladoceran microfossil assemblages at Kråkenes, western Norway, with quantitative reconstruction of temperature changes. J. Paleolim. 23:67-76.

Erni A, Forcart L, Harri H, 1943. [Fundstellen pleistocaener Fossilien in der "Hochterrasse" von Zeli (Kt. Luzem) und in der Morane der größten Eiszeit von Auswil bei Rohrbach (Kt. Bern)].[Article in German]. Eciogae Geol. Hel.

Flössner D, 1964. [Zur Cladoceranfauna des Stechlin-Gebietes. II. Ökologische Untersuchungen über die litoralen Arten].[Article in German]. Limnologica 2:35-103.

Flössner D, 1972. Branchipoda, Branchiura. Tierwelt Deutschl. 60:1-501.

Flössner D, 2000. [Die Haplopoda und Cladocera (ohne Bosminidae) Mitteleuropas].[Book in German]. Backhuys
Publishers, Leiden: 428 pp.

Frey DG, 1958. The Late Glacial cladoceran fauna of a small lake. Arch. Hydrobiol. 54:209-275.

Frey DG, 1962. Cladocera from the Eemian interglacial of Denmark. J. Paleontol. 36:1133-1154.

Frey DG, 1986. Cladocera analysis, p. 667-692. In: B.E. Berglund (ed.), Handbook of Holocene palaeoecology and palaeohydrology. J. Wiley \& Sons, Chichester.

Gąsiorowski M, 2002. Changes in Cladocera (Crustacea) assemblage of Lake Kruklin (Masurian Lake District) caused by an artificial drop in water level. Limnol. Rev. 2:131-136.

Gąsiorowski M, Szeroczyńska K, 2004. Abrupt changes in species structure of genus Bosmina during the history of the Ostrowite Lake (northern Poland). Hydrobiologia 526:137-144.

Gąsiorowski M, Hercman H, 2005. Recent sedimentation and eutrophication of Kruklin Lake after artificial drop in waterlevel in the middle of $19^{\text {th }}$ century. Stud. Quatern. 22:17-25.

Gibbard P, Kolfschoten T, 2004. The Pleistocene and Holocene epochs, p. 441-452. In: F.M. Gradstein, J.G. Ogg and A.G. Smith (eds.), A geologic time scale. Cambridge University Press, Cambridge.

Goulden CE, 1964. The history of the cladoceran fauna of Esthwaite Water (England) and its limnological significance. Arch. Hydrobiol. 60:1-53.

Granoszewski W, 2003. Late Pleistocene vegetation history and climatic changes at Horoszki Duże, eastern Poland: a palaeobotanical study. Acta Palaeobotanica Suppl. 4:3-95.

Harmsworth RV, 1968. The developmental history of Blelham Tarn (England) as shown by animal microfossils, with special reference to the Cladocera. Ecol. Monogr. 38:223-241.

Hann BJ, Karrow PF, 1984. Pleistocene paleoecology of the Don and Scarborough Formations, Toronto, Canada, based on cladocera microfossils at the Don Valley Brickyard. Boreas 13:377-391.

Hann BJ, Karrow PF, 1993. Comparative analysis of cladoceran microfossils in the Don and Scarborough Formations, Toronto, Canada. J. Paleolimnol. 9:223-241.

Hofmann W, 1986. Developmental history of the Grosser Plöner See and the Schöhsee (north Germany): cladoceran analysis, with special reference to eutrophication. Arch Hydrobiology. Suppl. 74:259-287.

Hofmann W, 1987. Stratigraphy of Cladocera (Crustacea) and Chironomidae (Insecta: Diptera) in three sediment cores from the Central Baltic Sea as related to paleo-salinity. Int. Rev. Ges. Hydrobiol. 72:97-106.

Hofmann W, 1993. Late-Glacial/Holocene changes of the climatic and trophic conditions in three Eifel Maar lakes, as indicated by faunal remains. I. Cladocera. Lect. Notes Earth Sci. 49:393-420.

Hofmann W, 2000. Response of the chydorid faunas to rapid climatic changes in four alpine lakes at different altitudes. Palaeogeogr. Palaeoclimatol. Palaeoecol. 159:281-292.

Jeppesen E, Jensen JP, Skovgaard H, Hvidt ChB, 2001. Changes in the abundance of planktivorous fish in Lake Skanderborg during the past two centuries - a palaeoecological approch. Palaeogeogr. Palaeoclimatol. Palaeoecol. 172:143-152.

Jeppesen E, Kronvang B, Olesen JE, Søndergaard M, Hoffmann CC, Andersen HE, Lauridsen TL, Liboriussen L, Meerhoff M, Beklioglu M, Özen A, 2011. Climate change effect on nitrogen loading from catchment in Europe: implications for 
nitrogen retention and ecological state of lakes and adaptations. Hydrobiologia 663:1-21.

Jessen K, Milthers V, 1928. Stratigraphical and paleontological studies of interglacial fresh-water deposits in Jutland and North-west Germany. Danm. Geol. Unders. 48 1-380.

Kadota S, 1975. A quantative study of the microfossils in a 200meter-long core sample from lake Biwa. Paleolimnol. Lake Biwa Jpn Pleistocene 85:354-367.

Korhola A, 1990. Paleolimnology and hydroseral development of the Kotasuo Bog, Southern Finland, with special reference to the Cladocera. Ann. Acad. Sci. Fenn. 155:5-40.

Korhola A, Rautio M, 2001. Cladocera and other branchiopod crustaceans, p. 5-41. In: J.P. Smol, H.J.B. Birks and W.M. Last (eds), Tracking environmental change using lake sediments. 4. Zoological indicators. Kluwer Academic Publishers, Dordrecht.

Kołaczek P, Karpińska-Kołaczek M, Petera-Zganiacz J, 2012. Vegetation patterns underclimate changes of the Eemian and Early Weichselian in Central Europe inferred from a palynological sequence from Ustków (central Poland). Quatern. Int. 268:9-20.

Kołaczek P, Niska M, Mirosław-Grabowska J, Gałka M, 2016. Periodic lake-peatland shifts under the Eemian and Early Weichselian climate changes in Central Europe on the basis of multi-proxy studies. Palaeogeogr. Palaeoclimatol. Palaeoecol. 461:29-43

Krause-Dellin D, Steinberg C, 1986. Cladoceran remains as indicators of lake acidification. Hydrobiologia 143:129-134.

Kupryjanowicz M, 2007. [Water level changes in the Eemian lakes and peat-bogs in the north Podlasie].[Article in Polish with English abstract]. Prz. Geol. 55:336-342.

Kupryjanowicz M, 2008. Vegetation and climate of the Eemian and Early Vistulian lakeland in northern Podlasie. Acta Palaeobot. 48:3-130.

Kupryjanowicz M, Ciszek D, Mirosław-Grabowska J, Marciniak B, Niska M, 2004. Multi-proxy study of Eemian deposits from Solniki (North-Eeastern Poland) - preliminary results, p. 55. In: Proceedings Workshop "Reconstruction of Quaternary palaeoclimate and palaeoenvironments and their abrupt changes", Bialowieza, Poland.

Kupryjanowicz M, Ciszek D, Mirosław-Grabowska J, Marciniak B, Niska M, 2005. Two climatic oscillations during the Eemian Interglacial preliminary results of multiproxy researches of palaeolake at Solniki, NE Poland, p. 53-57. Polish Geological Institute Special Papers n. 16.

Kurek S, Preidl M, 2001. [Objaśnienia do arkusza Trześcianka Szczegółowej mapy geologicznej Polski w skali 1: 50,000].[In Polish]. Central Geological Archives, PIG, Warszawa.

Lindner L, 1992. [Czwartorzęd. Osady, metody badań, stratygrafia].[In Polish]. Wyd. PAE.

Mangerud J, 1989. Correlation of the Eemian and the Weichselian with deep sea oxygen isotope stratigraphy. Quatern. Int. 3-4:1-4.

Mamakowa K, 1989. Late Middle Polish Glaciation, Eemian and Early Vistulian vegetation at Imbramowice near Wrocław and the pollen stratigraphy of this part of the Pleistocene in Poland. Acta Palaeobot. 29:11-176.

Marks L, 2002. Last glacial maximum in Poland. Quaternary Sci. Rev. 21:103-110.
Mirosław-Grabowska J, Niska M, 2005. Isotopic and Cladocera records of climate changes of Early Eemian at Besiekierz (Central Poland). Geol. Quart. 49:67-74.

Mirosław-Grabowska J, Niska M, 2007a. Isotope and Cladocera data and interpretation from the Eemian optimum and postoptimum deposits, Kaliska palaeolake (Central Poland). Quatern. Int. 175:155-167.

Mirosław-Grabowska J, Niska M, 2007b. Reconstruction of environmental conditions of Eemian palaeolake at Studzieniec (Central Poland) on the basis of stable isotope and Cladocera analyses. Quatern. Int. 162-163:195-204.

Mirosław-Grabowska J, Niska M, Sienkiewicz E, 2009. Evolution of the palaeolake at Ruszkówek (central Poland) during the Eemian interglacial based on isotopic, cladoceran and diatom data. J. Paleolimnol. 42:467 481.

Mirosław-Grabowska J, Niska M, Kupryjanowicz M, 2015. Reaction of lake environment on the climatic cooling - Transition from the Eemian Interglacial to Early Vistulian on the basis of Solniki palaeolake sediments (NE Poland). Quatern. Int. 386:158-170.

Mirosław-Grabowska J, Niska M, Roman M, 2016. Long (MIS $5 e-3)$ environmental history of a paleolake in central Poland recorded in the succession from Kubłowo. Quatern. Int. Doi: 10.1016/j.quaint.2016.06.027

Mirosław-Grabowska J, Gąsiorowski M, 2010. Changes of water level in the Eemian palaeolake at Imbramowice (SW Poland) based on isotopic and cladoceran data. Quaternary Res. 73:143-150.

Musiał A, 1992. Studium rzeźby glacjalnej północnego Podlasia (summary: The study of the glacial sculpture in north Podlasie). Rozprawy Uniwersytetu Warszawskiego, 403.

Nalepka D, Walanus A, 2003. Data processing in pollen analysis. Acta Palaeobot. 43:125-134.

Nauwerck A, 1991. The history of the genus Eubosmina in Lake Mondsee (Upper Austria). Hydrobiologia 225:87-103.

Nazarova L, 2012. Chironomids in Quaternary permafrost deposits in the Siberian Arctic. Chironomus Newsl. Chironomid Res. 25:39-42.

Nevalainen L, Luoto TP and Sarmaja-Korjonen K, 2008. Late Holocene water-level changes in Lake Iso Lehmälampi, southern Finland, reflected in subfossil cladocerans and chironomids. Stud. Quatern. 25:33-42.

Nevalainen L, Luoto TP, Kultti S, Sarmaja-Korjonen, K 2013. Spatio-temporal distribution of sedimentary Cladocera (Crustacea: Branchiopoda) in relation to climate. Journal of Biogeography 40: 1548-1559.

Nevalainen L, Luoto, TP, 2016. Relationship between cladoceran (Crustacea) functional diversity and lake trophic gradients. Funct. Ecol doi:10.1111/1365-2435.12737

Niska M, 2008. [Interpretacja zmian środowiska jeziornego w interglacjale eemskim na podstawie analizy kopalnych Cladocera].[PhD Thesis in Polish]. Pomeranian University in Słupsk.

Niska M, 2012. Fossil Cladocera remains in the Eemian sediments - preservation, frequency and dominant species. Stud. Quatern. 29:31- 43.

Niska M, 2015. History of the development of Eemian Interglacial lakes on the basis of Cladocera subfossil analysis (Central and Eastern Poland). Limnol. Rev. 15:85-94.

Niska M, Roman M, 2014. Development of the Kublowo palae- 
olake, central Poland, during the Eemian interglacial as against subfossil cladocera analysis - Preliminary results. Stud. Quatern. 31:31-37.

Niska M, Kołodziej A, 2015. History of development and terrestrialization of Lake Starowlany in the Eemian Interglacial based on Cladocera analysis (Sokółka Hills, NE Poland). Stud. Quatern. 32:43-52.

Novakova K, 2005. Cladoceran fauna from the archeological site vladar in Czech Republic. Stud. Quatern. 22: 51-54.

Pawłowski D, 2011. Evolution of an Eemian lake based on Cladocera analysis (Konin area, Central Poland). Acta Geol. Polon. 61:441-450.

Pisias NG, Martinson DG, Moore TC, Shackleton NJ, Prell W, Hays J, Boden G, 1984. High resolution stratigraphic correlation of benthic oxygen isotopic records spanning the last 300000 year. Marine Geol. 56:119-136.

Poulsen E, 1944. Entomostraca from a late-glacial lacustrine deposit at Næstved, Denmark. Meddelelser fra Dansk Geologisk Forening 10:405-416.

Robertsson A-M, 2000. The Eemian interglacial in Sweden, and comparison with Finland. Geologie en Mijnbouw. Neth. J. Geosci. 79:325-333.

Rybak JI, Błędzki LA, 2010. [Słodkowodne skorupiaki planktonowe].[Book in Polish]. University of Warsaw: 368 pp.

Gandouin E, Ponel P, Andrieu-Ponel V, Franqu E, de Beaulieu JL, Reille M, Guiter F, Brulhet J, Lallier-Vergès E, Keravis D, von Grafenstein U, Veres D, 2007. Past environment and climate changes at the last Interglacial/Glacial transition (Les Échets, France) inferred from subfossil chironomids (Insecta). Geoscience 339:337-346.

Sarmaja-Korjonen K, Alhonen P, 1999. Cladoceran and diatom evidence of lake-level fluctuations from a Finnish lake and the effect of aquatic-moss layers on microfossil assemblages. J. Paleolim. 22:277-290.

Shackleton NJ, Sánchez-Goñi MF, Pailler D, Lancelot Y, 2003. Marine Isotope Substage 5e and the Eemian interglacial. Global Planet. Change 3:151-155.

Shackleton NJ, Opdyke ND, 1976. Oxygen-isotope and paleomagnetic stratigraphy of Pacific core V28-239. Late Pleistocene to Latest Pleistocene. Geol. Soc. Am. Mem. 145. Available from: http://memoirs.gsapubs.org/content/145/449. full.pdf

Shumate BC, Schelske CL, Crisman TL, Kenney WF, 2002. Response of the cladoceran community to trophic state change in Lake Apopka, Florida. J. Paleolim. 27:71-77.

Szeroczyńska K, 1985. [Cladocera jako wskaźnik ekologiczny w późnoczwartorzędowych osadach jeziornych Polski Północnej].[Article in Polish]. Acta Palaeontol. Polon. 30:3-69.

Szeroczyńska, K. 1998a. [Wioślarki (Cladocera, Crustacea) jako źródło informacji w badaniach osadów jeziornych].[Article in Polish]. Stud. Geol. Polon. 112:9-28.

Szeroczyńska K, 1998b. Palaeolimnological investigations in Poland based on Cladocera (Crustacea). Palaeogeogr. Palaeoclimatol. Palaeoecol. 140:335-345.

Szeroczyńska K, 1991. [Wioślarki (Cladocera) w osadach Jeziora Skrzetuszewskiego], p. 122-128. In: K. Tobolski (ed.), [Wstęp do paleoekologii Lednickiego Parku Krajobrazowego]. [Book in Polish]. Biblioteka Studiów Lednickich.

Szeroczyńska K, 2002. Human impact on lakes recorded in the remains of Cladocera (Crustacea). Quatern. Int. 95-96:165-174.

Szeroczyńska K, 2006. The significance of subfossil Cladocera in stratigraphy of Late Glacial and Holocene. Stud. Quatern. 23:37-45.

Szeroczyńska K, Sarmaja-Korjonen K, 2007. Atlas of subfossil Cladocera from central and northern Europe. Friends of Lower Vistula Society, Świecie: 87 pp.

Szeroczyńska K, Zawisza E, 2007. [Paleolimnologia - historia rozwoju jezior w Polsce w świetle badań fauny wioślarek].[Article in Polish]. Stud. Limnol. Telmatol. 1: 51-59.

Tsukada M, 1972. The history of lake Nojiri, Japan. Trans. Conn. Acad. Art. Sci. 44:339-365.

Whiteside MC, 1970. Danish chydorid Cladocera: modern ecology and core studies. Ecol. Monogr. 40:79-118.

Whiteside MC, Swindoll MR, 1988. Guidelines andlimitations to cladoceran paleoecological interpretations. Palaeogeogr. Palaeoclimatol. Palaeoecol 62:405-412. 